\title{
CLEFT LIP AND PALATE: SEASONAL INCIDENCE, BIRTH WEIGHT, BIRTH RANK, SEX, SITE, ASSOCIATED MALFORMATIONS AND PARENTAL AGE
}

\author{
A STATISTICAL SURVEY
}

\author{
BY \\ G. R. FRASER and J. S. CALNAN* \\ From the Population Genetics Research Unit, Medical Research Council, Headington, Oxford
}

(RECEIVED FOR PUBLICATION NOVEMBER 23, 1960)

Cleft palate, with or without cleft lip, is one of the more common congenital malformations in man. Two recent English surveys have reported a birth incidence of about one in 600 (MacMahon and McKeown, 1953; Pleydell, 1960) and this conforms well to careful surveys carried out in other countries of Europe (Fogh-Andersen, 1942) and the U.S.A. (Ivy, 1957).

For the past 10 years it has been the practice of the Plastic Surgery Unit at the Churchill Hospital to record in cases of this malformation, information regarding birth weight, date of birth, age of parents and birth rank. The site of the cleft (left, right or central) was always noted and in most cases the presence of any additional congenital malformations. In all, data are available in 456 cases, though the full information is not given in every instance.

The present paper deals with an analysis of these data in an attempt to throw light on possible aetiological mechanisms of this deformity. Group I refers to cases of isolated harelip, Group II to isolated cleft palate and Group III to combined harelip with cleft palate (Davis and Ritchie, 1922).

\section{The Present Inquiry}

Edwards (1958a) and Record and Edwards (1958) have detected a strong seasonal trend in the incidence of anencephaly and congenital dislocation of the hip respectively. Thus it seemed worthwhile to analyse the present data, especially as Edwards (1961) has noted a seasonal tend in cases of Group I cleft lip, and our analysis is by the method described in his paper (Table 1). Birth weight, birth rank, sex incidence, site of cleft and associated abnormalities are shown in Tables 2-6.

\footnotetext{
- Present address: Department of Experimental Surgery, Postgraduate Medical School of London, Ducane Road, W.12.
}

The control series for parental age (Table 7) was obtained in the following way. Parental age was recorded in 1,026 consecutive births at University College Hospital from March 1956 to October 1957. A regression was established for father's age on mother's age for each birth rank separately and for the total material. These data could not be used as a control series because of the different age and birth rank distribution of hospital, as opposed to domiciliary, deliveries.

However, using the material in the RegistrarGeneral's report (1954) for maternal age, the expected paternal age could be calculated, using the regressions established as above.

\section{Discussion}

The pathogenesis of these malformations is controlled not by any single factor, but by a number of factors both hereditary and environmental, and by interactions between them. Furthermore, the members of a surgical series, as presented here, have only one feature in common-the nature of the lesion to be repaired-and otherwise represent a heterogeneous collection of different entities. Data of this nature cannot differentiate between the roles of heredity and environment in the causation of this condition, still less define clearly any aetiological factors. It can, however, provide pointers in this direction.

Seasonal Incidence. It has been shown by these results (Table 1) that seasonal influences appear to play no significant part in the causation of these malformations. This is in contrast to the findings of Edwards (1961).

Birth Weight. Birth weights are on the whole 
TABLE 1

SEASONAL INCIDENCE

\begin{tabular}{|c|c|c|c|c|c|c|c|c|c|c|c|c|c|c|c|}
\hline \multirow{2}{*}{ Cleft Group } & & \multicolumn{12}{|c|}{ Birth Month } & \multirow{2}{*}{$\chi^{2}$} & \multirow{2}{*}{ Significance } \\
\hline & & 1 & 2 & 3 & 4 & 5 & 6 & 7 & 8 & 9 & 10 & 11 & 12 & & \\
\hline$\underset{\text { III }}{\text { II }}$ & & $\begin{array}{r}4 \\
19 \\
14\end{array}$ & $\begin{array}{r}10 \\
14 \\
6\end{array}$ & $\begin{array}{r}3 \\
21 \\
16\end{array}$ & $\begin{array}{r}11 \\
18 \\
8\end{array}$ & $\begin{array}{l}10 \\
19 \\
17\end{array}$ & $\begin{array}{r}5 \\
18 \\
10\end{array}$ & $\begin{array}{l}10 \\
14 \\
11\end{array}$ & $\begin{array}{r}5 \\
11 \\
16\end{array}$ & $\begin{array}{r}9 \\
16 \\
7\end{array}$ & $\begin{array}{r}7 \\
23 \\
13\end{array}$ & $\begin{array}{r}7 \\
9 \\
16\end{array}$ & $\begin{array}{r}8 \\
13 \\
16\end{array}$ & $\begin{array}{l}1 \cdot 56 \\
1 \cdot 91 \\
1 \cdot 63\end{array}$ & $\begin{array}{l}0.5>p>0 \cdot 3 \\
0.5>p>0.3 \\
0.5>p>0.3\end{array}$ \\
\hline Total cases ... & $\ldots$ & 37 & 30 & 40 & 37 & 46 & 33 & 35 & 32 & 32 & 43 & 32 & 37 & 0.41 & $0.9>p>0.8$ \\
\hline
\end{tabular}

TABLE 2

BIRTH WEIGHT

\begin{tabular}{|c|c|c|c|c|c|c|}
\hline Cleft Group & Sex & Totals & $\begin{array}{l}\text { Mean } \\
\text { Birth Weight } \\
\text { of Clefts }\end{array}$ & S.D. & $\begin{array}{c}\text { Mean } \\
\text { Birth Weights } \\
\text { of Controls }\end{array}$ & Significance \\
\hline$\vec{I}$ & $\begin{array}{l}\mathbf{M} \\
\mathbf{F}\end{array}$ & $\begin{array}{l}53 \\
26\end{array}$ & $\begin{array}{l}7 \cdot 61 \\
7 \cdot 31\end{array}$ & $\begin{array}{l}0 \cdot 14 \\
0 \cdot 25\end{array}$ & $\begin{array}{l}7 \cdot 61 \\
7 \cdot 31\end{array}$ & $\begin{array}{l}p>0 \cdot 10 \\
p>0.10\end{array}$ \\
\hline II & $\begin{array}{l}\mathbf{M} \\
\mathbf{F}\end{array}$ & $\begin{array}{l}69 \\
83\end{array}$ & $\begin{array}{l}7 \cdot 63 \\
7 \cdot 03\end{array}$ & $\begin{array}{l}0 \cdot 15 \\
0 \cdot 12\end{array}$ & $\begin{array}{l}7 \cdot 61 \\
7 \cdot 31\end{array}$ & $\begin{array}{c}p>0.10 \\
0.02>p>0.01\end{array}$ \\
\hline III & $\begin{array}{l}\mathbf{M} \\
\mathbf{F}\end{array}$ & $\begin{array}{l}96 \\
46\end{array}$ & $\begin{array}{l}7 \cdot 45 \\
7 \cdot 13\end{array}$ & $\begin{array}{l}0 \cdot 14 \\
0 \cdot 20\end{array}$ & $\begin{array}{l}7 \cdot 61 \\
7 \cdot 31\end{array}$ & $\begin{array}{l}p>0.10 \\
p>0.10\end{array}$ \\
\hline
\end{tabular}

Controls from Birmingham series of McKeown and Gibson (1951) and MacMahon and McKeown (1953) corrected for parity.

TABLE 3

BIRTH RANK

\begin{tabular}{|c|c|c|c|c|c|c|c|c|c|c|c|}
\hline \multirow{2}{*}{ Cleft Group } & \multicolumn{9}{|c|}{ Position in Family } & \multirow{2}{*}{$\chi^{2}$} & \multirow{2}{*}{ Significance } \\
\hline & 1 & 2 & 3 & 4 & 5 & 6 & 7 & 8 & 9 & & \\
\hline I & 35 & 21 & 14 & 8 & 4 & 1 & 0 & 1 & 2 & 0.56 & $0.5>p>0.3$ \\
\hline II & 74 & 54 & 22 & 7 & 7 & 4 & 3 & 3 & 2 & 0.05 & $0.9>p>0.8$ \\
\hline III & 51 & 42 & 25 & 14 & 6 & 4 & 1 & 0 & 0 & $0 \cdot 16$ & $0.7>p>0.5$ \\
\hline Total cases & 160 & 117 & 61 & 29 & 17 & 9 & 4 & 4 & 4 & 0.53 & $0.5>p>0.3$ \\
\hline
\end{tabular}

The statistical analysis is by the method of Edwards (1958b). The control series is from figures for the whole country published by the Registrar-General for 1954, this being the median birth year of the present series.

low (Table 2). This is not unexpected with a severe congenital malformation and it is interesting that in Group I this decrease is least. It is most marked in Group II females and this conforms to the findings of Lutz (1959).

Birth Rank. The birth rank distribution (Table 3) is not significantly different from normal. However, if it is analysed by the sex of the patient, we find a marked primiparity effect in Group I females.

\begin{tabular}{ll|rrrrrrrrr}
\hline & \multicolumn{1}{|c|}{} & \multicolumn{10}{|c}{ Group I (cleft lip only) } \\
\cline { 2 - 4 } &.. & 1 & 2 & 3 & 4 & 5 & 6 & 7 & 8 & 9 \\
Females &.. & 16 & 5 & 2 & 4 & 1 & 0 & 0 & 1 & 1 \\
Males &.. & 19 & 16 & 12 & 4 & 3 & 1 & 0 & 0 & 1 \\
\hline
\end{tabular}

This effect is not repeated in any other group. (Normal ratio for birth rank 1 to birth rank $2=$
1.32. In Group II males it is $1 \cdot 25$ and in females $1 \cdot 48$, and in Group III males $1 \cdot 04$, females $1 \cdot 50$.)

Incidence, Sex and Site. It has been argued that Groups I and III form one sub-division of this malformation and Group II another. The main argument in favour of this hypothesis has been the similar excess of affected males in Groups I and III (about 2:1 in most series) as opposed to equality or even a slight excess of females in Group II. The present data support this hypothesis (Tables 4 and 5). The possible reasons for the male excess in Groups I and III will be discussed later. The incidence by site conforms well to the data of FoghAndersen. No explanation can be given at the moment for the preference of this lesion for the left side. The incidence on the various groups con- 
TABLE 4

INCIDENCE AND SEX

\begin{tabular}{|c|c|c|c|c|c|}
\hline $\begin{array}{l}\text { Cleft } \\
\text { Group }\end{array}$ & Total & $\begin{array}{l}\% \text { of } \\
\text { Series }\end{array}$ & Males & Females & $\underset{(\%)}{\text { Males }}$ \\
\hline II & $\begin{array}{r}93 \\
211 \\
152\end{array}$ & $\begin{array}{l}20 \cdot 4 \\
46 \cdot 3 \\
33 \cdot 3\end{array}$ & $\begin{array}{r}61 \\
94 \\
103\end{array}$ & $\begin{array}{r}32 \\
117 \\
49\end{array}$ & $\begin{array}{l}65 \cdot 6 \\
44 \cdot 5 \\
67 \cdot 8\end{array}$ \\
\hline Totals . . & 456 & - & 258 & 198 & $56 \cdot 5$ \\
\hline
\end{tabular}

TABLE 5

SITE OF CLEFT

\begin{tabular}{|c|c|c|c|}
\hline$\underset{\text { Group }}{\text { Cleft }}$ & Right & Left & Bilateral \\
\hline $\begin{array}{l}\text { II } \\
\text { III }\end{array}$ & $\begin{array}{l}27(29 \cdot 0 \%) \\
\text { Central } \\
31(20 \cdot 4 \%)\end{array}$ & $\begin{array}{l}48(51 \cdot 6 \%) \\
82(53.9 \%)\end{array}$ & $\begin{array}{l}18(19 \cdot 4 \%) \\
39(25.7 \%)\end{array}$ \\
\hline
\end{tabular}

TABLE 6

ASSOCIATED ABNORMALITIES

\begin{tabular}{|c|c|c|}
\hline$\underset{\text { Group }}{\text { Cleft }}$ & Nos. & Abnormality \\
\hline $\bar{I}$ & 1 & Syndactyly \\
\hline II & $\begin{array}{r}19 \\
4 \\
2 \\
1 \\
1 \\
1\end{array}$ & $\begin{array}{l}\text { Pierre Robin's syndrome (retrognathism) } \\
\text { Klippel Feil's syndrome } \\
\text { Mucous fistulae of lower lip and syndactyly } \\
\text { Treacher Collins' syndrome } \\
\text { Ectrodactyly } \\
\text { Talipes }\end{array}$ \\
\hline III & $\begin{array}{l}1 \\
1 \\
1\end{array}$ & $\begin{array}{l}\text { Hypospadias } \\
\text { Micrognathia } \\
\text { Polydactyly }\end{array}$ \\
\hline
\end{tabular}

forms well to the Birmingham birth data (MacMahon and McKeown 1953), but not to the operative series of Fogh-Andersen who found about $50 \%$ of Group

TABLE 7

PARENTAL AGE

\begin{tabular}{c|c|c|c|c|c}
\hline \multirow{2}{*}{$\begin{array}{c}\text { Cleft } \\
\text { Group }\end{array}$} & \multirow{2}{*}{ Totals } & \multicolumn{2}{|c|}{ Father } & \multicolumn{2}{|c|}{ Mother } \\
\cline { 3 - 5 } & & $\begin{array}{c}\text { Mean } \\
\text { Age }\end{array}$ & S.D. & $\begin{array}{c}\text { Mean } \\
\text { Age }\end{array}$ & S.D. \\
\hline I & 83 & $31 \cdot 4$ & $6 \cdot 48$ & $28 \cdot 3$ & $5 \cdot 81$ \\
III & 163 & 32.9 & $8 \cdot 43$ & $29 \cdot 0$ & $5 \cdot 85$ \\
Controls & 136 & $33 \cdot 9$ & $7 \cdot 78$ & $29 \cdot 3$ & $6 \cdot 05$ \\
& & $31 \cdot 6$ (var. = 0.14) & $28 \cdot 3$ & \\
\hline
\end{tabular}

Comparison with controls:

\begin{tabular}{|c|c|c|}
\hline \multicolumn{2}{|c|}{ Group } & \multirow{2}{*}{$\begin{array}{r}\text { Significance } \\
\mathrm{p}>0 \cdot 1 \\
\mathrm{p}>0.1\end{array}$} \\
\hline I & $\begin{array}{l}\text { Fathers } \\
\text { Mothers }\end{array}$ & \\
\hline II & $\begin{array}{l}\text { Fathers } \\
\text { Mothers }\end{array}$ & $0.1>\underset{p}{p}>0.05$ \\
\hline III & $\begin{array}{l}\text { Fathers } \\
\text { Mothers }\end{array}$ & $\begin{array}{l}0.01>p>0.002 \\
0.1>p>0.05\end{array}$ \\
\hline
\end{tabular}

III, and roughly equal incidence of Groups I and II. The reason for this discrepancy is not clear.

Associated Malformations. This is an operative and not a birth series. The incidence of congenital malformations (Table 6) would be expected to be lower, therefore, than in the series of MacMahon and McKeown (1953) since all gross malformations would have been excluded by early death. Group II, however, is very interesting from this point of view since isolated cleft palate seems to occur with remarkable frequency as a constituent of syndromes which are inherited in a dominant manner such as those of Pierre Robin and Treacher Collins and ectrodactyly. In addition, a father and son are included with the syndrome of cleft palate with mucous fistulae of the lower lip (Calnan, 1952; Van der Woude, 1954). In our family syndactyly was also present.

The syndrome of Pierre Robin is, however, numerically by far the most important. In the past such children tended to die soon after birth due to the tongue falling back causing asphyxia; they are now surviving with better nursing care, and the condition of the lower jaw improves with age. This syndrome is inherited in an irregularly dominant manner and the gene concerned may account for quite a large proportion of Group II cases. An analysis of parental age was made separately for these complex syndromes and for simple Group II cases, but revealed no differences which could not be attributed to chance.

Parental Age. MacMahon and McKeown (1953) showed that maternal age but not birth rank was raised in Groups I and III but not Group II. We were unable to confirm this for Group I, but found a marked increase in Group III (Table 7). A smaller increase in Group II could well have been due to chance. Furthermore, our data suggest that the more important factor in the raised parental age was the paternal and not the maternal age. In an attempt to explain the puzzling asymmetrical distribution of the lesion and the difference in sex incidence an analysis of variance was performed to determine whether this raised paternal age in Group III could be correlated with patients of a particular sex or with a particular site of lesion.

\begin{tabular}{|c|c|c|c|}
\hline Group III & Males & Females & \\
\hline $\begin{array}{l}\text { Right } \quad \ldots \\
\text { Left } \\
\text { Bilateral }\end{array}$ & $\begin{array}{l}23 \\
43 \\
23\end{array}$ & $\begin{array}{r}8 \\
26 \\
13\end{array}$ & $\begin{aligned} x^{2} & =1.39 \\
p & =0.5\end{aligned}$ \\
\hline
\end{tabular}


Analysis of variance (paternal age) is as follows:

\begin{tabular}{|c|c|c|c|c|}
\hline & $\begin{array}{l}\text { Degrees of } \\
\text { Freedom }\end{array}$ & $\begin{array}{l}\text { Sum of } \\
\text { Squares }\end{array}$ & $\begin{array}{l}\text { Mean } \\
\text { Square }\end{array}$ & $\begin{array}{l}\text { Signifi- } \\
\text { cance }\end{array}$ \\
\hline $\begin{array}{l}\text { Between sexes } \\
\text { Between sites } \\
\text { Interactions } \\
\text { Residual } \quad \text {. }\end{array}$ & $\begin{array}{r}1 \\
2 \\
2 \\
130\end{array}$ & $\begin{array}{r}72 \\
28 \\
41 \\
8,692\end{array}$ & $\begin{array}{l}72 \\
14 \\
20 \cdot 5 \\
66 \cdot 86\end{array}$ & $\begin{array}{l}p>0.2 \\
p>0.2\end{array}$ \\
\hline
\end{tabular}

This analysis does not show any differences in paternal age by sex or site which are unlikely to be due to chance. However, the age of fathers of female patients is higher than that of males.

\begin{tabular}{cc|c|c}
\hline Patients & & $\begin{array}{c}\text { Mean Age of } \\
\text { Father }\end{array}$ & $\begin{array}{c}\text { Mean Age of } \\
\text { Mother }\end{array}$ \\
\hline $\begin{array}{ccc}47 \text { females } \\
89\end{array}$ & $\ldots$ & $34 \cdot 6$ & $29 \cdot 7$ \\
& & $33 \cdot 1$ & $29 \cdot 1$ \\
\hline
\end{tabular}

Such large differences were not seen in Groups I and II.

\begin{tabular}{|c|c|c|c|c|}
\hline Group & Patients & & $\begin{array}{l}\text { Mean Age of } \\
\text { Father }\end{array}$ & $\begin{array}{c}\text { Mean Age of } \\
\text { Mother }\end{array}$ \\
\hline$I$ & $\begin{array}{l}28 \text { females } \\
55 \text { males }\end{array}$ & $\ddot{\cdots}$ & $\begin{array}{l}31 \cdot 5 \\
31 \cdot 0\end{array}$ & $\begin{array}{l}28 \cdot 5 \\
28 \cdot 0\end{array}$ \\
\hline II & $\begin{array}{l}87 \text { females } \\
76 \text { males }\end{array}$ & $\ddot{*}$ & $\begin{array}{l}32 \cdot 5 \\
33 \cdot 4\end{array}$ & $\begin{array}{l}28 \cdot 7 \\
29 \cdot 3\end{array}$ \\
\hline
\end{tabular}

An examination of parental age by birth rank was also made. The full results are not reproduced here, but the following table gives the ages of the parents of first births.

\begin{tabular}{|c|c|c|c|c|}
\hline Group & Patients & & $\begin{array}{l}\text { Mean Age of } \\
\text { Father }\end{array}$ & $\underset{\text { Mother }}{\text { Mean Age of }}$ \\
\hline $\begin{array}{r}\text { I } \\
\text { II } \\
\text { III }\end{array}$ & $\begin{array}{l}19 \text { males } \\
14 \text { females } \\
30 \text { males } \\
37 \text { females } \\
29 \text { males } \\
18 \text { females }\end{array}$ & $\begin{array}{l}\cdots \\
\cdots \\
\cdots \\
\cdots \\
\cdots\end{array}$ & $\begin{array}{l}28 \cdot 1 \\
30 \cdot 4 \\
30 \cdot 1 \\
28 \cdot 6 \\
31 \cdot 9 \\
31 \cdot 8\end{array}$ & $\begin{array}{l}25 \cdot 6 \\
27 \cdot 6 \\
26 \cdot 6 \\
26 \cdot 0 \\
28 \cdot 1 \\
26 \cdot 9\end{array}$ \\
\hline Controls & $\ldots$ & $\ldots$ & $28 \cdot 5$ & $25 \cdot 3$ \\
\hline
\end{tabular}

This suggests an excess of elderly primiparae among the parents of female Group I children and among the parents of male Group III children.

\section{Conclusions}

An attempt has been made to provide pointers to the elucidation of the aetiology of this complex of congenital malformations. The excess of males in Groups I and III suggests that females are less susceptible to the interactions of polyfactorial genetical and environmental factors which are concerned in the pathogenesis of this sub-division. Thus, there is evidence that advanced maternal age at first birth may predispose to a Group I malformation in females and to a more severe
Group III malformation in males. In the same way other less potent factors may cause a cleft lip in males, with a lower threshold of resistance, but nothing at all in females.

The increased paternal age, in Group III especially, suggests (Penrose, 1955) that fresh paternal mutations are concerned in the pathogenesis of this condition. Such mutations might be especially important in the fathers of female patients, who are older, since it has been argued above that females may have a higher threshold of resistance to environmental and genetical factors responsible for these malformations.

There is suggestive evidence, both because of the very different sex ratio in Group II and because of the incidence of isolated cleft palate as a constituent of various complex syndromes thought to be inherited in a dominant manner, that single genes may play a large part against a background of polyfactorial genes and environmental factors in the determination of this condition. The moderately raised parental age, once again more marked for fathers than mothers, suggests that fresh mutations may play a role. Such fresh mutations both in this Group and in Group III compensate for genes lost due to early death, as in Pierre Robin's syndrome.

We wish to thank the various surgeons concerned for permission to examine records of their cases and one of us (J.S.C.) wishes to thank Dr. A. C. Stevenson for kindly providing accommodation in the Population Genetics Research Unit, and the University of Oxford for a generous research grant during this study. We wish to thank Dr. J. H. Edwards for advice on treatment of these data and for allowing us to see a manuscript before publication.

\section{REFERENCES}

Calnan, J. (1952). Congenital double lip: record of a case with a note on the embryology. Brit. J. plast. Surg., 5, 197

Davis, J. S. and Ritchie, H. P. (1922). Classification of congenital clefts of the lip and palate. J. Amer. med. Ass., 79, 1323.

Edwards, J. H. (1958a). Congenital malformations of the central nervous system in Scotland. Brit. J. prev. soc. Med., 12, 115 . (1958b). A note on the interpretation of $n \times 2$ tables. Ibid., 12,141 .

(1961). The recognition and estimation of cyclic trends. Ann. hum. Genet., 25, 83

Fogh-Andersen, P. (1942). Inheritance of harelip and cleft palate. Op. dom. Biol. hered. hum., Kbh., Vol. 4.

Ivy, R. H. (1957). Congenital anomalies as recorded on birth certificates in the Division of Vital Statistics of the Pennsylvania Department of Health for the period 1951-55 inclusive. Plast. reconstr. Surg., 20, 400.

Lutz, K. R. (1959). Birth weights in cleft palate. Cleft Palate Bull., 9, 47.

McKeown, T. and Gibson, J. R. (1951). Observations on all births $(23,970)$ in Birmingham, 1947; II: Birth weight. Brit. J. prev. soc. Med., 5, 98.

MacMahon, B. and McKeown, T. (1953). The incidence of harelip and cleft palate related to birth rank and maternal age. Amer. J. hum. Genet., 5, 176.

Penrose, L. S. (1955). Parental age and mutation. Lancet, 2, 312.

Pleydell, M. J. (1960). Anencephaly and other congenital abnormalities. An epidemiological study in Northamptonshire. Brit. med. J., 1, 309.

Record, R. G. and Edwards, J. H. (1958). Environmental influences related to the aetiology of congenital dislocation of the hip. Brit. J. prev. soc. Med., 12, 8.

Van der Woude, A. (1954). Fistula labii inferioris congenita and its association with cleft lip and palate. Amer. J. hum. Genet., 6. 244. 